by Dickerman et al, ${ }^{1}$ who reviewed a further 31 cases and thought that sarcoidosis might predispose to thrombocytopenia. Dacie ${ }^{2}$ reviewed 11 cases of haemolytic anaemia with sarcoidosis and believed the association to be real, though Scadding ${ }^{3}$ was less convinced. According to Dacie, haemolytic anaemia may co-exist with, precede, or postdate sarcoidosis by years and the result of Coomb's test is variable. Hypersplenism is apparently not responsible in most such cases, as the response is better to steroids than to splenectomy The cause is probably due to an altered immune responsiveness. The fact that immunoglobulins are often raised and the cellular immune response depressed in sarcoidosis, as in this case, is perhaps relevant. An example of cold haemagglutinin syndrome accompanying sarcoidosis was reported by Palazze et al ${ }^{4}$ who postulated that changes in host immunity might favour the appearance of sarcoidosis.

It would appear unlikely that sarcoidosis causes either thrombocypenia or haemolytic anaemia directly because they may occur years apart. Perhaps all three conditions are differing manifestations of an underlying disorder of immunity. Their appearance in this one subject suggests the possibility of a genuine association.

I am indebted to Dr R N Johnston, Professor K G Lowe, and Dr D G Adamson for their kind permission to report this case. I thank also Dr P Ford, Dr J B MacGillivray, and Dr A F Todd for their help with laboratory investigations.

${ }^{1}$ Dickerman, J D, Holbrook, $P$ R, and Zinkham, W $H$, Fournal of Paediatrics, 1972, 81, 758.

2 Dacie, J V, The Haemolytic Anaemias, 2nd edn, vol III, p 921 London; Churchill Livingstone, 1967

3 Scadding, J G, Sarcoidosis, p 253-260 London, Eyre and Spottiswoode, 1967

4 Palazzo, E, et al, Acta Haematologica, 1972, 48, 331

Department of Respiratory Medicine, King's Cross Hospital, Dundee DD3 8EA

P d'A SEMPLE, MB, MRCP, registrar

\section{Hypergastrinaemia in a peptic ulcer patient with antral gastrin cell hyperplasia}

Intractable ulceration in the presence of a tumour that produces gastrin is one form of the Zollinger-Ellison syndrome (ZES). The increasing. use of radioimmunoassay of gastrin in the diagnosis of this condition has shown that in some patients the raised plasma levels lie between normal and what might confidently be ascribed to an- autonomous source of the hormone from neoplastic cells. ${ }^{1}$ In these cases the rise may be explained by the hyperplasia of the antral gastrin $(G)$ cells $^{23}$ which has been described in some patients with duodenal ulcer. The gastric acid and plasma gastrin response in these patients to inhibitory and stimulatory tests of gastrin release have not been described.

\section{Case report}

A 60 -year-old man presented with loss of weight $(19 \mathrm{~kg})$, diarrhoea, epigastric discomfort, general weakness, and anorexia. Two years previously he had had a gastrojejunostomy without vagotomy for a duodenal ulcer of 25 years' standing. A barium meal and enema radiograph showed a gastrojejunocolic fistula. At gastroscopy a large stomach with increased fold size and excessive resting juice was noted together with an ulcer on the jejunal side of the gastroenterostomy. Overnight acid secretion was 1.41 with a total acid output of $84 \mathrm{mmol}(84 \mathrm{~m} \mathrm{Eq})$; basal acid on three occasions was $10.6,5.5$, and $4.0 \mathrm{mmol} / \mathrm{h}$ respectively; and maximal acid output to pentagastrin was $85.6 \mathrm{mmol} / \mathrm{h}$.

Peptide hormone studies-Serial daily plasma gastrin levels were 22 $31,23,25,30$, and $39 \mathrm{pmol} / 1(48,68,51,55,66,86 \mathrm{pg} / \mathrm{ml}$ ) (normal range for duodenal ulcer patients $5-18 \mathrm{pmol} / 1$. or $11-40 \mathrm{pg} / \mathrm{ml}$ ). These levels were lower than those previously encountered in our assays of patients with the ZES (range 40-1000 $\mathrm{pmol} / \mathrm{l}$ ). A secretin test ${ }^{4}$ (one unit $/ \mathrm{kg} \mathrm{GIH} \mathrm{secretin}$ intravenously) produced a fall in plasma gastrin from 25 tol5 pmol/1 (55-33 $\mathrm{pg} / \mathrm{ml}$ ) and a fall in acid output from a basal $3.9 \mathrm{mmol} / \mathrm{h}$ to $1.9 \mathrm{mmol} / \mathrm{h}$, as opposed to the rise which occurs in the ZES. A calcium infusion test raised the gastrin level slightly, from 31 to $40 \mathrm{pmol} / 1(68-88 \mathrm{pg} / \mathrm{ml})$ but not the $100 \%$ expected in the ZES; acid output rose from 10.6 to $23.3 \mathrm{mmol} / \mathrm{h}$ during the third infusion hour. A protein stimulation test in the form of an English breakfast produced a substantial rise in the gastrin level from 23 to $68 \mathrm{pmol} / 1(51-150 \mathrm{pg} / \mathrm{ml})$ in contrast to the minimal rise seen in the ZES. Thus, no dynamic study supported the diagnosis of the ZES. The plasma vasoactive intestinal peptide was normal $(32 \mathrm{ng} / 1) .^{5}$ A Polya partial gastrectomy was performed and the colonic fistula closed without resection. No tumour was found in the pancreas or duodenum. Postoperative recovery was uneventful. Immunofluorescent studies ${ }^{2}$ showed moderate $\mathbf{G}$ cell hyperplasia mainly within the middle zone of the glands (See fig).

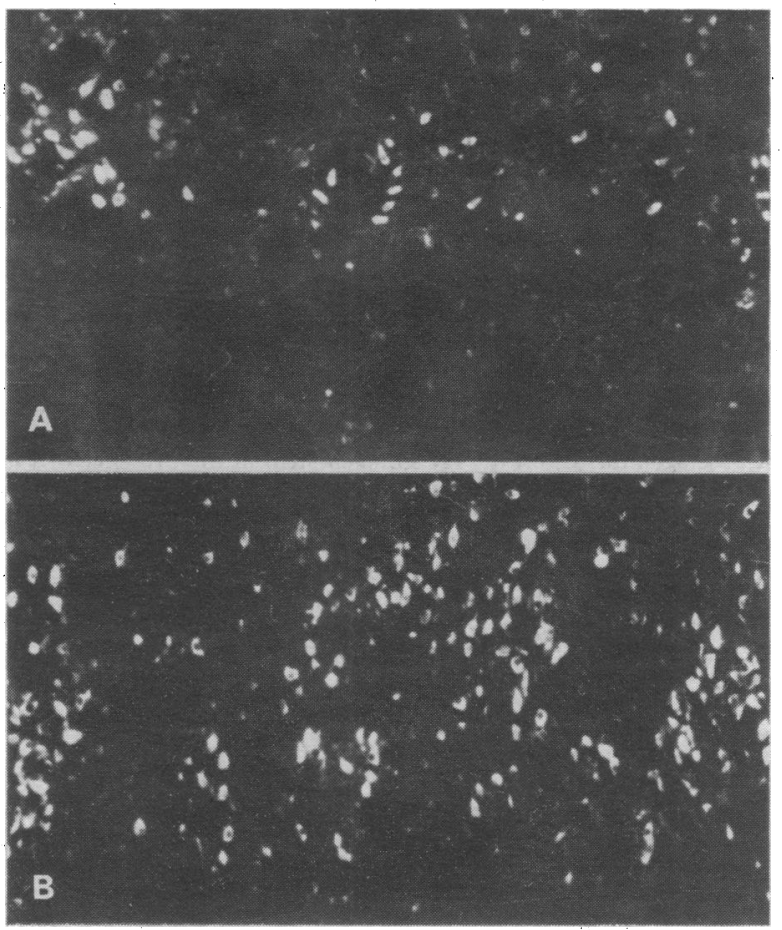

Immunofluorescent preparations (a) of human antral tissue, showing normal number and distribution of $G$ cells (b), of patient's antrum, showing moderate $G$ cell hyperplasia. $(\times 155$.

\section{Comment}

This patient was correctly diagnosed preoperatively by the secretin test, and the diagnosis was confirmed both by a pronounced rise in gastrin after a protein stimulus and a rise of less than $100 \%$ after a calcium infusion. The normal response of the $G$ cell to these stimuli suggests that the set point for the control of gastrin release is deranged but the cell is certainly not autonomous. This condition may be representative of merely the extreme upper limit of the duodenal ulcer population or perhaps of a separate subgroup with a different pathophysiology and aetiology.

This work was carried out with the aid of an MRC grant.

1 Walsh, J H, and Grossman, M I, Mount Sinui fournal of Medicine, $1973,40,374$.

2 Polak, J M, Stagg, B, and Pearse, A G, Gut, 1972, 13, 501.

3 Cowley, D J, et al, Gut, 1973, 14, 25.

Thompson, J C, et al, Surgery, Gynecology and Obstetrics, 1975, 140, 721.

5 Bloom, S R, Polak, J M, and Pearse, A G E, Lancet, 1973, 2, 14.

Surgical Unit, St Mary's Hospital, London W2 1NY

R C G RUSSELL, MB, FRCS, assistant director

Department of Medicine and Histochemistry, Royal Postgraduate Medical School, Hammersmith Hospital, London W12 OHS

S R BLOOM, MB, MRCP, lecturer and honorary consultant W A DAVIES, MB, MRCP, honorary registrar in medicine

JULIA M POLAK, MD, MRCPATH, lecturer

$P$ I REED, $\operatorname{FRCP}(C)$, MRCP, senior lecturer in medicine and consultant physician 